\title{
Chemical composition, cytotoxic and antioxidative activities of ethanolic extracts of propolis on HCT-116 cell line
}

Jovana B Žižića, , Nenad L Vuković ${ }^{\mathrm{b}}$, Milka B Jadranin ${ }^{\mathrm{c}}$, Boban D Anđelkovićd, Vele V

Tešević $^{\mathrm{d}}$, Miroslava M Kacaniova ${ }^{\mathrm{e}}$, Slobodan B Sukdolak ${ }^{\mathrm{b}}$ and Snežana D Markovića ${ }^{\mathrm{a}}$

${ }^{a}$ Department of Biology and Ecology, Faculty of Science, University of Kragujevac, Radoja

Domanovića 12, 34000 Kragujevac, Serbia

${ }^{b}$ Department of Chemistry, Faculty of Science, University of Kragujevac, Radoja

Domanovića 12, 34000 Kragujevac, Serbia

${ }^{c}$ Institute of Chemistry, Technology and Metallurgy, University of Belgrade, Njegoševa 12,

11000 Belgrade, Serbia

${ }^{d}$ Faculty of Chemistry, University of Belgrade, Studentski trg 16, 11000 Belgrade, Serbia

${ }^{e}$ Department of Microbiology, Faculty of Biotechnology and Food Science, Slovak University

of Agriculture in Nitra, Tr. A. Hlinku 2, 94976 Nitra, Slovak Republic

This article has been accepted for publication and undergone full peer review but has not been through the copyediting, typesetting, pagination and proofreading process, which may lead to differences between this version and the Version of Record. Please cite this article as doi: $10.1002 /$ jsfa.6132

(C) 2013 Society of Chemical Industry

*Correspondence to: Jovana B Žižić, Department of Biology and Ecology, Faculty of Science, University of Kragujevac, Radoja Domanovića 12, 34000 Kragujevac, Serbia

E-mail: jovanazizic@kg.ac.rs 


\section{Abstract}

BACKGROUND: Propolis is a complex resinous sticky substance that honeybees collect from buds and exudates of various plants. Due to propolis versatile biological and pharmacological activities, it is widely used in medicine, cosmetics and food industry. The aim of this study was to evaluate cytotoxic and antioxidative effects of various ethanolic extracts of propolis (EEP) on human colon cancer cell line (HCT-116) and compare it with their composition. HPLC-DAD method was used to determine the chemical composition of propolis samples.

RESULTS: The most abundant flavonoids in all samples were chrysin, pinocembrin and galangin (12.697- $\left.40.811 \mu \mathrm{g} \mathrm{mg}{ }^{-1}\right)$. On the other hand, main phenolic acids were caffeic, ferulic and isoferulic acid. Dose and time-dependent inhibition of cell growth of HCT-116 cells was observed in all propolis samples, with $\mathrm{IC}_{50}$ values ranging from 26.33 to $143.09 \mu \mathrm{g}$ $\mathrm{mL}^{-1}$. Differences in cytotoxic activity of propolis samples were associated with differences in their composition. Our results showed that all EEP samples reduced both superoxide anion radical and nitrite levels and also had strong DPPH scavenging activity.

CONCLUSION: All tested propolis samples had pronounced cytotoxic and antioxidative activities.

Key words: Propolis; Polyphenols; Cytotoxicity; Antioxidants; HCT-116 cell line 


\section{INTRODUCTION}

Propolis (bee glue) is a complex resinous sticky substance that honeybees collect from buds and exudates of various plants and mix it with their own salivary secretions and waxes. It is thought to be used as a protective barrier and sterilant in beehives. Due to its numerous pharmacological properties, it has been used in folk medicine since ancient times. ${ }^{1}$ The precise composition of raw propolis varies with the source. In general, it is composed of $50 \%$ resin and vegetable balsam, $30 \%$ wax, $10 \%$ essential and aromatic oils, $5 \%$ pollen and $5 \%$ other various substances, including organic debris. ${ }^{2}$ More than 300 constituents have been identified in different propolis samples. ${ }^{3}$ Propolis contains a variety of chemical compounds such as polyphenols (flavonoid aglycones, phenolic acids and their esters, phenolic aldehydes, alcohols and ketones), sesquiterpene quinones, coumarins, steroids, amino acids, and inorganic compounds. ${ }^{4}$

Due to propolis versatile biological and pharmacological activities, it is widely used in medicine, cosmetics and food industry. Propolis and its derivatives possess numerous biological properties such as antibacterial, antioxidant, antiviral, anti-inflammatory, antitumoral, immunomodulatory, anti-HIV-1, antineurodegenerative and antituberculosis. ${ }^{5-10}$ Furthermore, most of its components are natural constituents of food and recognized as safe substances. $^{11}$

In literature, no data can be found about the composition and biological activities of Serbian propolis extracts. Therefore, this paper aims to characterize the phenolic composition of propolis samples by HPLC-DAD, as well as to characterize their cytotoxic and antioxidant activities. 


\section{EXPERIMENTAL}

\section{Chemicals}

The phenolic standards apigenin, tectochrysin, galangin, hesperetin, kaempferol, luteolin, myricetin, naringenin, pinocembrin, chrysin, isorhamnetin, quercetin, $p$-hydroxybenzoic acid, caffeic acid, ferulic acid, and $p$-coumaric acid were purchased from Extrasynthese (GenaySedex, France). The analytical grade reagents - formic acid and ethanol, were obtained from Sigma (USA), and methanol and acetonitrile with HPLC purity were purchased from J.T. Baker (Holland). Water was treated in a Mili-Q water purification system (TGI Pure Water Systems, USA). Sodium nitrite $\left(\mathrm{NaNO}_{2}\right)$ and phosphoric acid were purchased from "Zorka pharma”, Serbia. Dublecco's Modified Eagle Medium (DMEM) was obtained from GIBCO, Invitrogen, USA. Fetal bovine serum (FBS) and trypsin-EDTA were from PAA (The cell culture company), Austria. Dimethyl sulfoxide (DMSO), nitro blue tetrazolium (NBT), ethidium bromide and 3-[4,5-dimethylthiazol-2-yl]-2,5-diphenyltetrazolium bromide (MTT) were obtained from SERVA (Germany) and sulfanilic acid from MP Hemija, Serbia. 2,2-

Diphenyl-1-picrylhydrazyl (DPPH) radical was obtained from Acros organic, New Jersey, USA. N-(1-Naphthyl)ethylenediamine was purchased from Fluka Chemie AG, Buchs, Switzerland. 5-Fluorouracil was obtained from Sigma, USA.

\section{Sample collection and propolis extract preparation}

On the basis of literature data that seasonal variations in propolis composition are not significant (only minor quantitative changes) and the fact that composition of the plant source determines the chemical composition of propolis, we chose seven different locations that cover a relatively large area for our experiment. ${ }^{12,13}$ 
Seven distinct propolis samples (S1-S7) were collected in the summer of 2011 from Apis mellifera hives located in different apiaries in the southwest of Serbia (locations of samples: S1, Mrckovina; S2, Babine; S3: Miljevici, S4: Jabuka, S5: Velika Zupa, S6: Zalug, S7: Kacevo). Raw propolis samples were obtained by scraping the frames of beehives, and stored at $4{ }^{\circ} \mathrm{C}$ until analysis. Prior to the extraction, the samples of propolis (10 g) (S1-S7) were grounded and homogenized. The samples were extracted in dark with $96 \%$ ethanol (1:20 $\mathrm{w} / \mathrm{v}$ ), and mixed with magnetic stirrer at room temperature for $24 \mathrm{~h}$. The resulting mixtures were filtered and stored overnight at $4{ }^{\circ} \mathrm{C}$ to induce the crystallization of dissolved waxes. The resultant solutions were filtered, concentrated on a rotary evaporator under reduced pressure at $40{ }^{\circ} \mathrm{C}$, giving resinous red to brown products (EEP). The extracts were stored at 4 ${ }^{\circ} \mathrm{C}$, protected from light, until use.

\section{HPLC-DAD analysis of ethanolic extracts of propolis (EEP)}

Experiments were performed on an Agilent 1200 Series HPLC system (Agilent Technologies, USA), equipped with degasser, autosampler and DAD detector. For chromatographic analysis, a Zorbax Eclipse Plus C18 column (150×4.6 mm i.d.; $1.8 \mu \mathrm{m})$ was used. The mobile phase consisted of $0.2 \%(\mathrm{v} / \mathrm{v})$ solution of formic acid in water (A) and acetonitrile (B). The gradient program was used as follows, with a total analysis time of $120 \mathrm{~min}$ : (0-3 min) $10 \%$ $\mathrm{B}$, (3-8 min) $10-25 \% \mathrm{~B},(8-11 \mathrm{~min}) 25 \% \mathrm{~B},(11-18 \mathrm{~min}) 25-30 \% \mathrm{~B},(18-48 \mathrm{~min}) 30-40 \%$ $\mathrm{B},(48-68 \mathrm{~min}) 40-60 \% \mathrm{~B},(68-88 \mathrm{~min}) 60-90 \% \mathrm{~B},(88-100 \mathrm{~min}) 90 \% \mathrm{~B},(100-101 \mathrm{~min}) 90-$ $100 \% \mathrm{~B}$, and (101-120 min) $10 \% \mathrm{~B}$. The flow rate was $1.20 \mathrm{~mL} \mathrm{~min}^{-1}$, the injection volume was $5 \mu \mathrm{L}$, while the temperature of the column oven was set at $40{ }^{\circ} \mathrm{C}$. The chromatographic data were processed using Agilent Technologies ChemStation software, equipped with a spectral identification module of the compounds separated on the column. 
By using DAD detector, absorption was detected in a range of wavelengths from $190 \mathrm{~nm}$ to $450 \mathrm{~nm}$, while chromatograms were recorded at following wavelengths: $260 \mathrm{~nm}$ for $\mathrm{p}$ hydroxybenzoic acid, myricetin, quercetin, kaempferol, isorhamnetin, chrysin, galangin and tectochrysin; $280 \mathrm{~nm}$ for naringenin, hesperetin and pinocembrin; $320 \mathrm{~nm}$ for caffeic acid, caffeic acid phenylethyl ester (CAPE), p-coumaric acid and luteolin; and $340 \mathrm{~nm}$ for ferulic acid, isoferulic acid and apigenin.

For quantitative analysis of the seven samples of ethanolic extracts of propolis, each analyte was dissolved in methanol at a concentration of $1000 \mu \mathrm{g} \mathrm{mL} L^{-1}$, and then diluted with methanol to appropriate concentrations $\left(0.2-500 \mu \mathrm{g} \mathrm{mL}^{-1}\right)$ for the establishment of calibration curves. All of the standard solutions were kept at $4{ }^{\circ} \mathrm{C}$.

Amounts of $10 \mathrm{mg}$ of each extract (S1-S7) were dissolved in $1 \mathrm{~mL}$ of methanol and filtered through $0.45 \mu \mathrm{m}$ filter (Millipore) prior to HPLC injection. An aliquot of $5 \mu \mathrm{L}$ of solution was injected in triplicate for HPLC analysis.

Range of linearity

An aliquot of $5 \mu \mathrm{L}$ of solution for each calibration standard solution was injected in triplicate for HPLC analysis. The calibration curve was constructed by plotting the peak areas versus the concentration for each analyte (Appendix 1).

Limits of detection (LOD) and limits of quantification (LOQ)

The stock solutions were diluted to a series of appropriate concentrations with methanol, and an aliquot of the diluted solutions was injected for HPLC analysis. The limits of detection (LOD) and limits of quantification (LOQ) for each analyte were determined under the present chromatographic conditions at a signal-to-noise ratio $(\mathrm{S} / \mathrm{N})$ of about 3 and 10 , respectively (Appendix 1). 


\section{Determination of cytotoxic and antioxidative activities of ethanolic extracts of propolis (EEP)}

Cell preparation and culturing

Human colon cancer, HCT-116 cell line was obtained from American Type Culture Collection. Cells were maintained in DMEM medium, supplemented with $100 \mathrm{~g} \mathrm{~L}^{-1}$ heatinactivated FBS, $100 \mathrm{IU} \mathrm{mL} \mathrm{m}^{-1}$ of penicillin and $100 \mu \mathrm{g} \mathrm{mL} \mathrm{m}^{-1}$ of streptomycin. Cells were cultured in a humidified atmosphere of $5 \% \mathrm{CO}_{2}$ at $37^{\circ} \mathrm{C}$. Cells were grown in $75 \mathrm{~cm}^{2}$ culture bottles supplied with $15 \mathrm{~mL}$ of DMEM.

Treatment of cell line

EEP samples (S1-S7) were prepared as stock solutions $\left(1000 \mu \mathrm{g} \mathrm{mL}^{-1}\right)$ in $10 \mathrm{~g} \mathrm{~L}^{-1} \mathrm{DMSO}$. Working solutions in the concentration range of $1-500 \mu \mathrm{g} \mathrm{mL} L^{-1}$ were prepared prior to testing. HCT-116 cells (10000 cells per well) were seeded in a 96-well microtitre plates (exponentially growing viable cells were used throughout the assay) and $24 \mathrm{~h}$ later, after cell adherence, culturing medium was replaced with $100 \mu \mathrm{L}$ of medium containing various doses of ethanolic propolis extracts at different concentrations $(1,10,50,100,250$ and $500 \mu \mathrm{g} \mathrm{mL}$

${ }^{1}$ ) for cell viability assay and concentrations $\left(10,50,100\right.$ and $\left.500 \mu \mathrm{g} \mathrm{mL}^{-1}\right)$ for NBT and Griess assay, except in control wells, where only the nutrient medium was added to the cells. Cells were incubated with EEP samples for $24 \mathrm{~h}$ and $72 \mathrm{~h}$ prior to testing.

\section{Cell Viability Assay (MTT Assay)}

Cell viability was determined by MTT assay. ${ }^{14}$ At the end of the treatment period, $25 \mu \mathrm{L}$ of MTT solution (final concentration $5 \mathrm{mg} \mathrm{mL}^{-1} \mathrm{PBS}$ ) was added to each well and incubated at $37{ }^{\circ} \mathrm{C}$ in $5 \% \mathrm{CO}_{2}$ for $3 \mathrm{~h}$. The colored crystals of produced formazan were dissolved in 150 
$\mu \mathrm{L}$ DMSO. The absorbance was measured at $570 \mathrm{~nm}$ on microplate reader (ELISA 2100C).

To determine cell viability (\%), the absorbance (A) of a sample with cells grown in the presence of various concentrations of the investigated extracts was divided by the control (the A of control cells grown only in culturing medium) and multiplied by 100 . It was implied that the A of the blank was always subtracted from the A of the corresponding sample with target cells. We have also calculated the half maximal inhibitory concentration $\left(\mathrm{IC}_{50}\right)$, delineated as concentration of substance eliciting inhibition of cell growth by $50 \%$ compared with a vehicle-treated control. As a positive control, 5-Fluorouracil (5-FU) was used. A DMSO solution was used as a negative control. All experiments were done in triplicate.

Determination of superoxide anion radical (NBT assay)

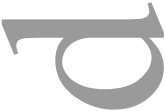

The concentration of superoxide anion radical $\left(\mathrm{O}_{2}^{--}\right)$in the sample was determined by spectrophotometric method and is based on the reduction of nitroblue tetrazolium (NBT) to nitroblue-formazan in the presence of $\mathrm{O}_{2} \cdot{ }^{-15}$ Assay was performed by adding $10 \mu \mathrm{L}$ of $5 \mathrm{mg}$ $\mathrm{mL}^{-1} \mathrm{NBT}$ to each well and then the cells were incubated for $45 \mathrm{~min}$ at $37^{\circ} \mathrm{C}$ in $5 \% \mathrm{CO}_{2}$. To quantify the formazan product, formazan was solubilized in $10 \mu \mathrm{L}$ DMSO and the resulting colour reaction was measured spectrophotometrically on microplate reader at $570 \mathrm{~nm}$ (ELISA 2100C). The amount of NBT reduced was determined by the change in absorbance at 560 $\mathrm{nm}$, based on molar extinction coefficient for monoformazan that is $15,000 \mathrm{M}^{-1} \mathrm{~cm}^{-1}$ and the results were expressed as nmol $\mathrm{NBT} \mathrm{mL}^{-1}$.

Nitric oxide (NO) measurement (Griess Assay)

The spectrophotometric determination of nitrites $-\mathrm{NO}_{2}{ }^{-}$(indicator of the nitric oxide $-\mathrm{NO}$ level) was performed by using the Griess method. ${ }^{16}$ Experiments were performed at room temperature or at $37{ }^{\circ} \mathrm{C}$ in a warm room. Nitrite standard solution $(100 \mathrm{mM})$ was serially 
diluted from $100-1.6 \mu \mathrm{M}$ in triplicate in a 96-well plate. Equal volumes $1 \mathrm{mg} \mathrm{mL}^{-1}$ of $\mathrm{N}-(1-$ naphthyl)ethylenediamine and $10 \mathrm{mg} \mathrm{mL}^{-1}$ of sulfanilic acid (solution in $50 \mathrm{~g} \mathrm{~L}^{-1}$ phosphoric acid) were mixed to form the Griess reagent immediately prior to application to cells. The absorbance at $550 \mathrm{~nm}$ was measured by using microplate reader (ELISA 2100C) following incubation (usually 5-10 min). The results were expressed in nmol nitrite $\mathrm{mL}^{-1}$ from a standard curve established in each test, constituted of known molar concentrations of nitrite.

\section{DPPH assay}

The method used by Takao et al. ${ }^{17}$, was adopted with suitable modifications. 2,2-diphenyl-1picrylhydrazyl (DPPH) radical $(8 \mathrm{mg})$ was dissolved in methanol $(100 \mathrm{~mL})$ to obtain a concentration of $80 \mu \mathrm{g} \mathrm{mL} L^{-1}$. Serial dilutions were carried out with stock solutions $(1000 \mu \mathrm{g}$ $\mathrm{mL}^{-1}$ ) of the EEP to obtain concentrations of $500,250,125,62.5,31.25,15.63,7.81,3.9$ and $1.95 \mu \mathrm{g} \mathrm{mL} \mathrm{m}^{-1}$. Diluted solutions (2 $\mathrm{mL}$ each) were mixed with DPPH $(2 \mathrm{~mL})$ and allowed to stand for 30 and $60 \mathrm{~min}$ for any reaction to occur. The absorbance was recorded at $517 \mathrm{~nm}$ by using a Jenway 6105 UV/VIS spectrophotometer. The experiment was performed in triplicate and the average absorbance was noted for each concentration. The $\mathrm{IC}_{50}$ value, which is the concentration of the test extract that reduces $50 \%$ of the initial free radical concentration, was calculated as $1 \mu \mathrm{g} \mathrm{mL} \mathrm{mL}^{-1}$. Ascorbic acid and BHT were used as reference standards, at the same concentrations in methanol as were used for the tested extracts. The control sample was prepared containing the same volume without test extracts and reference compounds. The radical-scavenging activity of the tested samples, expressed as percentage inhibition of DPPH, was calculated according to the formula:

$\operatorname{IC}(\%)=\left[\left(\mathrm{A}_{0}-\mathrm{A}_{\mathrm{t}}\right) / \mathrm{A}_{0}\right] \times 100 ;$

where $A_{t}$ is the absorbance value of the tested sample and $A_{0}$ is the absorbance value of blank sample, at a particular time. Percentage inhibition after 30 and 60 min was plotted against 
concentration, and the equation for the line was used to obtain the $\mathrm{IC}_{50}$ value. $\mathrm{A}$ lower $\mathrm{IC}_{50}$ value indicates greater antioxidant activity.

\section{Statistical Analysis}

The data is expressed as mean values \pm standard errors (SE). Biological activity was performed in triplicate for each dose. Data were expressed as mean \pm standard error and oneway analysis of variance (ANOVA) was performed to test for significant differences and between means and Fisher's Least Significant Difference (LSD) post hoc analysis using SPSS statistical software package (SPSS for Windows, version 17, 2008). Differences at $\mathrm{p} \leq$ 0.05 were considered significant. The magnitude of correlation between variables and the $\mathrm{IC}_{50}$ values were calculated from the dose curves by a computer program (CalcuSyn).

\section{RESULTS AND DISCUSSION}

\section{Analysis by HPLC-DAD}

Qualitative analysis

Analyzing the ethanolic extracts of propolis by the HPLC-DAD on the basis of the retention times, as well as UV spectra of standard compounds, five phenolic acids ( $p$-hydroxybenzoic acid, caffeic acid, p-coumaric acid and ferulic acid), one phenolic acid ester (caffeic acid phenylethyl ester, CAPE) and twelve flavonoids (myricetin, luteolin, quercetin, naringenin, apigenin, kaempferol, hesperetin, isorhamnetin, chrysin, pinocembrin, galangin and tectochrysin) were unequivocally identified (Figure 1). 


\section{Quantitative analysis}

Equations for regression lines obtained from calibration curves, correlation coefficients, limits of detection, and limits of quantification and range of linearity of the target compounds were presented in Appendix 1.

Linear regressions of these standard compounds showed good linearity in the range of 0.098 $500.000 \mu \mathrm{g} \mathrm{mL}^{-1}$ with correlation coefficient $\left(\mathrm{r}^{2}\right)$ ranging from 0.9986 to 0.9999 . This allows the determination of these compounds over a wide range of concentrations. On the other hand, limits of detection were found within the range of $0.058-1.271 \mu \mathrm{g} \mathrm{mL}^{-1}$, while the limits of quantification were within 0.098-2.119 $\mu \mathrm{g} \mathrm{mL}^{-1}$ (Appendix 1).

The content of phenolic acids and flavonoids of the seven ethanolic propolis samples (S1-S7) is reported in Table 1. In analyzed samples, with the total concentration of $25.415 \mu \mathrm{g} \mathrm{mg}^{-1}$, S5 contains the highest level of phenolic acids. The most common compound from this group was caffeic acid found in the ranges of $5.989 \mu \mathrm{g} \mathrm{mg}^{-1}$ (in S7) to $8.931 \mu \mathrm{g} \mathrm{mg}^{-1}$ (in S1) (except in S3; $3.372 \mu \mathrm{g} \mathrm{mg}^{-1}$ ). The content of caffeic acid phenylethyl ester (CAPE) was found in the range $6.053 \mu \mathrm{g} \mathrm{mg}^{-1}$ (in sample S3) to $8.209 \mu \mathrm{g} \mathrm{mg}^{-1}$ (in sample S5). Also, ferulic acid was found in high amount in S3 $\left(7.584 \mu \mathrm{g} \mathrm{mg}^{-1}\right)$, as well as isoferulic acid in samples S4, S5 and S6 (5.490 $\mu \mathrm{g} \mathrm{mg}^{-1}, 6.624 \mu \mathrm{g} \mathrm{mg}^{-1}$ and $5.263 \mu \mathrm{g} \mathrm{mg}^{-1}$, respectively). The lowest concentration was observed in the case of $p$-coumaric acid $\left(0.180 \mu \mathrm{g} / \mathrm{mg}-0.281 \mu \mathrm{g} \mathrm{mg}^{-1}\right)$. These results are quite similar to those obtained in investigations performed on propolis samples from Croatia, Bosnia and Hercegovina and Macedonia. ${ }^{18}$

Similarly to the above mentioned, the sample labeled as S5 contains the highest level of analyzed flavonoids and CAPE $\left(139.875 \mu \mathrm{g} \mathrm{mg}^{-1}\right.$ and $8.209 \mu \mathrm{g} \mathrm{mg}^{-1}$, respectively). On the other hand, with the total concentration of $59.058 \mu \mathrm{g} \mathrm{mg}^{-1}, \mathrm{~S} 3$ showed the lowest level of these compounds (Table 1). The most abundant compounds in all samples were chrysin, 
pinocembrin and galangin $\left(12.697 \mu \mathrm{g} \mathrm{mg}^{-1}-40.811 \mu \mathrm{g} \mathrm{mg} \mathrm{g}^{-1}\right)$, while other flavonoids and CAPE were detected in small amounts. Samples S5 and S1 were especially characteristic, showing a high level of chrysin, pinocembrin and galangin (S5: $40.811 \mu \mathrm{g} \mathrm{mg}^{-1}, 40.324 \mu \mathrm{g}$ $\mathrm{mg}^{-1}$ and $35.586 \mu \mathrm{g} \mathrm{mg}^{-1}$, respectively; S1: $34.124 \mu \mathrm{g} \mathrm{mg}^{-1}, 35.546 \mu \mathrm{g} \mathrm{mg}^{-1}$ and $30.432 \mu \mathrm{g}$ $\mathrm{mg}^{-1}$, respectively). From this aspect, our propolis samples showed similarity to analyzed samples from Bulgaria, Italy and Switzerland. ${ }^{19}$ In all analyzed extracts, myricetin, luteolin and hesperetin were observed in a concentration lower than $1.000 \mu \mathrm{g} \mathrm{mg}^{-1}$.

\section{Cytotoxic effects of ethanolic extracts of propolis}

Cytotoxic effects of the seven EEP samples were assessed on HCT-116 cell line. Results are presented as a percentage of cell viability compared to untreated, control cells (Figure 2). Dose and time-dependent inhibition of cell growth was observed in all cells treated with all seven propolis samples at tested concentration range. All propolis samples had pronounced cytotoxic effects at highest applied concentration ranging from 19 to $47 \%$ for $24 \mathrm{~h}$ treatment and 15 to $23 \%$ for $72 \mathrm{~h}$ treatment.

Results of in vitro cytotoxic activity of seven investigated EEP were also expressed by $\mathrm{IC}_{50}$ values, presented in Table 2. The most pronounced cytotoxic effect $24 \mathrm{~h}$ after treatment exhibited samples EEP S1 and S4 (184.08 and $191.13 \mu \mathrm{g} \mathrm{mL} \mathrm{L}^{-1}$, respectively) and $72 \mathrm{~h}$ after treatment propolis samples S4, S5 and S6 $\left(26.33,39.81\right.$ and $38.54 \mu \mathrm{g} \mathrm{mL}^{-1}$, respectively). Other propolis extracts exhibited only weak cytotoxic effect. According to the American National Cancer Institute (NCI), the criteria of cytotoxic activity for the crude extracts is $\mathrm{IC}_{50}$ $<30 \mu \mathrm{g} / \mathrm{mL}^{20}{ }^{20}$ In consideration to this criteria and observed $\mathrm{IC}_{50}$ values, we can conclude that propolis sample S4 has a strong antiproliferative effect on the HCT-116 cell line $72 \mathrm{~h}$ after treatment and that sample S5 and S6 also have significant antiproliferative effects, their $\mathrm{IC}_{50}$ values being on the upper limit. 
Several research groups showed that phenolic compounds, flavonoids and CAPE from propolis elicited protective effect both in in vitro and in vivo colon cancer models. ${ }^{21-25}$ Differences in cytotoxic activity of propolis samples are associated with differences in composition of phenolic acid, flavonoids and CAPE, which was observed by HPLC-DAD analysis. This corresponds with very pronounced antiproliferative effect of samples S4 and S5, having the highest level of phenolic acids, flavonoids and CAPE.

Cytotoxic effect of 5-fluorouracil was used as positive control to evaluate cytotoxic effects of propolis samples. Our data showed that $\mathrm{IC}_{50}$ value for 5 -fluorouracil $\left(0.81 \mu \mathrm{g} \mathrm{mL} \mathrm{m}^{-1}\right)$ was around 32 times higher than $\mathrm{IC}_{50}$ value of most cytotoxic propolis sample $\mathrm{S} 4\left(26.33 \mu \mathrm{g} \mathrm{\textrm {mL } ^ { - }}\right.$

$\left.{ }^{1}\right)$. Conversely, 5-fluorouracil used as a standard chemotherapeutic drug has around 62 times higher acute oral toxicity $\left(\mathrm{LD}_{50}=115 \mathrm{mg} \mathrm{kg}^{-1}\right)$ than propolis $\left(\mathrm{LD}_{50}=2000-7300 \mathrm{mg} \mathrm{kg}^{-1}\right)$ in mouse model. ${ }^{26}$ Due to its antiproliferative effects and low oral toxicity, propolis could be used over a prolonged period of time for chemoprevention and supportive therapy. The negative control DMSO had no inhibitory effect on the tested cell lines.

\section{Antioxidative properties of EEP on HCT-116 cells production of superoxide anion radical and nitrites}

In order to explain the mechanism of cytotoxic activities of EEP on the HCT-116 cell line, we followed antioxidative properties of investigated extracts on HCT-116 cells. The data presented in Table 3 present the release of $\mathrm{O}_{2}^{-{ }^{-}}$as nmol NBT $\mathrm{mL}^{-1}, 24 \mathrm{~h}$ and $72 \mathrm{~h}$ after incubation with seven ethanolic propolis extracts. Samples S1 and S2, at all concentrations $\left(10,50,100\right.$ and $\left.500 \mu \mathrm{g} \mathrm{mL} L^{-1}\right)$, induced significantly lower level of superoxide anion radical production in HCT-116 cells compared to control cells $24 \mathrm{~h}$ after treatment. All other samples did not have any significant impact on superoxide anion radical production at $500 \mu \mathrm{g} \mathrm{mL} \mathrm{L}^{-1}$ concentration. All propolis samples induced significantly lower level of superoxide anion radical in HCT-116 cells compared to control cells, except samples S5 and S7 at highest 
concentration applied that caused higher level of superoxide anion radical compared to control cells, $72 \mathrm{~h}$ after treatment.

Determination of the nitrite $\left(\mathrm{NO}_{2}^{-}\right)$concentration demonstrated that all ethanolic extracts of propolis at all concentrations applied were able to reduce the release of NO (Table 4) in comparison with control cells. All propolis extracts, except S7 at lowest and highest concentration, significantly reduced the level of nitrites after $72 \mathrm{~h}$ of exposure compared to $24 \mathrm{~h}$ exposure.

Some studies suggested that the antiproliferative effects of some polyphenol antioxidants on cancer cells are partially due to their prooxidant actions. ${ }^{27}$ In our experiment, propolis samples S5 and S7 that have highest phenolic acids content induced the highest levels of superoxide anion radical $72 \mathrm{~h}$ after treatment at highest concentration applied and maybe, at least in part, that could be the source of their good antiproliferative potential. On the other hand, due to their ability to scavenge and reduce the production of free radicals, and because they act as transition metal chelators, natural phenolic compounds may exert a major chemopreventive activity. ${ }^{28}$ Our data showed that all propolis samples had stronger antioxidant properties $72 \mathrm{~h}$ after treatment compared to $24 \mathrm{~h}$ treatment, since they reduce both levels of superoxide anion radical and nitrites and may have protective role against free radical production, that together with other factors are responsible for cellular aging and many conditions such as cancer, cardiovascular diseases, diabetes, arthritis, Parkinson disease and Alzheimer. ${ }^{29}$

\section{Free radical-scavenging activity of 2,2-diphenyl-1-picrylhydrazyl radical by ethanolic propolis extracts}

This assay is based on the measurements of the scavenging ability of extracts towards the stable 2,2-diphenyl-1-picrylhydrazyl radical (DPPH). The antioxidant activity was expressed 
as the $50 \%$ inhibitory concentration $\left(\mathrm{IC}_{50}\right)$ based on the amount of extract required for a 50 $\%$ decrease of the initial DPPH radical concentration. $\mathrm{IC}_{50}$ values of EEP samples $\mathrm{S} 1-\mathrm{S} 7$ are presented in Table 5 and are ranging from 55.45 to $118.46 \mu \mathrm{g} \mathrm{mL}^{-1}$. All samples showed lower radical-scavenging activities in comparison to butylated hydroxytoluene (BHT) and ascorbic acid standards. Samples S1, S4 and S7 had most effective scavenging activity $\left(\mathrm{IC}_{50}\right.$ values were $70.42,55.45$ and $56.68 \mu \mathrm{g} \mathrm{mL}^{-1}$, respectively).

Propolis samples with strong DPPH scavenging activity contained higher concentrations of antioxidative phenolic compounds compared to other samples, such as caffeic acid (S7 and S1), isoferulic acid (S4) and especially high levels of flavonoids with most abundant being chrysin, pinocembrin and galangin (S1). This positive corelation, however is not observed in all samples, since we should expect that sample S5 with highest amount of phenolic acids, flavonoids and CAPE has more pronounced scavenging activity because flavonoids and CAPE are found to be most effective antioxidant in propolis. ${ }^{30,31}$ Studies on volatiles, especially aroma-active components are reported to help improve the medicinal effect of propolis. $^{32}$

Polyphenolic compounds identified in our propolis samples, such as flavonols, are the most abundant flavonoids and are common compounds in the human diet. They are found in onions, apples and tea, with quercetin, kaempferol and myricetin being the three most common flavonols. Flavanones are mainly found in citrus fruit and flavones in celery.

Many research groups have done in vivo and in vitro studies of colon cancer and showed that tea, apples and onions extracts exhibited pronounced antioxidative and cytotoxic effects comparable to our results with propolis. ${ }^{33-35}$

\section{CONCLUSIONS}

Today propolis is widely used as a dietary supplement and is one of the richest sources of plant phenolics and polyphenolics and is claimed to improve health and prevent diseases such 
as inflammation, heart disease, diabetes and even cancer. We have determined chemical composition, on the basis of five standards of phenolic acids and twelve standards of flavonoids, by HPLC-DAD analysis in order to characterize phenolic acid and flavonoid content in propolis samples from Serbia.

We have evaluated antiproliferative effects of ethanolic extracts of propolis on human colon cancer cell line, HCT-116 and we observed that differences in cytotoxic activity of propolis samples are correlated with their differences in composition of phenolic acids and flavonoids, since samples rich in phenolic acids, flavonoids and CAPE also exhibited stronger cytotoxic effects.

Propolis is also reported to exert antioxidative activity due to its phenolic constituents. Our results showed that ethanolic extracts of propolis reduced both superoxide anion radical and nitrite levels and also had strong DPPH scavenging activity, but also that not only phenolic compounds are involved in this process, since there is no obvious correlation with their content of phenolic compounds and their antioxidative activity. For that reason additional qualitative and quantitative analyses of the propolis compounds are needed to explain exactly antioxidant activity of propolis.

Tested propolis samples had pronounced antiproliferative and antioxidative activities and may be considered as safe and healthy food supplements with chemopreventive properties, since relatively large amounts may be ingested without side effects, because of propolis low oral toxicity compared to standard chemotherapeutic drugs.

\section{ACKNOWLEGEMENTS}

This work was financed by the Serbian Ministry of Education and Science, grant numbers III41010 and 172053. 


\section{REFERENCES}

1 Marcucci MC, Propolis: chemical composition, biological properties and therapeutic activity. Apidologie 26: 83-99 (1995).

2 Bankova VS, de Castro SL and Marcucci MC, Propolis: recent advances in chemistry and plant origin. Apidologie 31: 3-16 (2000).

3 Khalil ML, Biological activity of bee propolis in health and disease. Asian Pac J Cancer Prev 7: 22-31 (2006).

4 Park YK, Alencar SM and Aguiar CL, Botanical origin and chemical composition of Brazilian propolis. J Agric Food Chem 50: 2502-2506 (2002).

5 Nieva Moreno MI, Isla MI, Cudmani NG, Vattuone MA and Sampietro AR, Screening of antibacterial activity of Amaicha del Valle (Tucumán, Argentina) propolis. $J$ Ethnopharmacol 68: 97-102 (1999).

6 Banskota $\mathrm{AH}$, Tezuka $\mathrm{Y}$ and Kadota S, Recent progress in pharmacological research of propolis. Phytother Res 15: 561-571 (2001).

7 Amoros M, Simõs CMO, Girre L, Sauvager F and Cormier M, Synergistic effect of flavones and flavonols against herpes simplex virus type 1 in cell culture. Comparison with the antiviral activity of propolis. J Nat Prod 55: 1732-1740 (1992).

8 Gekker G, Hu S, Spivak M, Lokensgard JR and Peterson PK, Anti-HIV-1 activity of propolis in $\mathrm{CD}^{+}$lymphocyte and microglial cell cultures. $J$ Ethnopharmacol 102: $158-163(2005)$.

9 Chen J, Long Y, Han M, Wang T, Chen Q and Wang R, Water-soluble derivative of propolis mitigates scopolamine-induced learning and memory impairment in mice. Pharmacol Biochem Behav 90: 441-446 (2008). 
10 Yildirim Z, Hacievliyagil S, Kutlu NO, Aydin NE, Kurkcuoglu M, Iraz M and Durmaz R, Effect of water extract of Turkish propolis on tuberculosis infection in guinea-pigs. Pharmacol Res 49: 287-292 (2004).

11 Tosi EA, Re E, Ortega ME and Cazzoli AF, Food preservative based on propolis: Bacteriostatic activity of propolis polyphenols and flavonoids upon Escherichia coli. Food Chem 104: 1025-1029 (2007).

12 Sforcin JM, Propolis and the immune system: A review. J Ethnopharmacol 113: 1-14 (2007).

13 Bankova V, Chemical diversity of propolis and the problem of standardization. $J$ Ethnopharmacol 100: 114-117 (2005).

14 Mosmann T, Rapid colorimetric assay for cellular growth and survival: application to proliferation and cytotoxicity assays. J Immunol Meth 65: 55-63 (1983).

15 Auclair C and Voisin, E, Nitroblue tetrazolium reduction, in Handbook of Methods for Oxygen Radical Research, ed. by Greenwald RA, Boka Raton, pp. 123-132 (1985).

16 Griess P, Bemerkungen zu der Abhandlung der HH. Weselsky und Benedikt Ueber einige Azoverbindungen. Chem Ber 12: 426-428 (1879).

17 Takao T, Kitatani F, Watanabe N, Yagi A and Sakata K, A simple screening method for antioxidants and isolation of several antioxidants produced by marine bacteria from fish and shellfish. Biosci Biotech Biochem 58: 1780-1783 (1994).

18 Barbarić M, Mišković K, Bojić M, Lončar MB, Smolčić-Bubalo A, Debeljak Ž and Medić-Šarić M, Chemical composition of the ethanolic propolis extracts and its effect on HeLa cells. J Ethnopharmacol 135: 772-778 (2011).

19 Bankova V, Popova M, Bogdanov S and Sabatini AG, Chemical composition of European propolis: expected and unexpected results. Zeitsch Naturforsch 57c: 530-533 (2002). 
20 Suffness M and Pezzuto JM, Assays Related to Cancer Drug Discovery, in Methods in Plant Biochemistry: Assays for Bioactivity, ed. by Hostettmann K, London, pp. 71$133(1990)$.

21 Banskota AH, Nagaoka T, Sumioka LY, Tezuka Y, Awale S, Midorikawa K and Kadota $\mathrm{S}$, Antiproliferative activity of the Netherlands propolis and its active principles in cancer cell lines. J Ethnopharmacol 80: 67-73 (2002).

22 Usia T, Banskota AH, Tezuka Y, Midorikawa K, Matsushige K and Kadota S, Constituents of Chinese propolis and their antiproliferative activities. J Nat Prod 65: $673-676$ (2002).

23 Rao CV, Desai D, Rivenson A, Simi B, Amin S and Reddy BS, Chemoprevention of colon carcinogenesis by phenylethyl-3-methylcaffeate. Cancer Res 55: 2310-2315 (1995).

24 Mahmoud N, Carothers M, Grunberger D, Bilinski T, Churchill R, Martucci C, Newmark $\mathrm{H}$ and Bertagnolli M, Plant phenolics decrease intestinal tumors in an animal model of familial adenomatous polyposis. Carcinogenesis 21: 921-927 (2000).

25 Nagaoka T, Banskota A, Tezuka Y, Saiki I and Kadota S, Selective antiproliferative activity of caffeic acid phenethyl ester analogues on highly liver-metastatic murine colon 26-L5 carcinoma cell line. Bioorg Med Chem 10: 3351-3359 (2002).

26 Burdock GA, Review of the biological properties and toxicity of bee propolis (propolis). Food Chem Toxicol 36: 347-363 (1998).

27 Cotelle N, Role of flavonoids in oxidative stress. Curr Top Med Chem 1: 569-590 (2001).

28 Kampa M, Nifli AP, Notas G and Castanas E, Polyphenols and cancer cell growth. Rev Physiol Biochem Pharmacol 159: 79-113 (2007).

29 Halliwell B, Free radicals, antioxidants, and human disease: curiosity, cause, or consequence? Lancet 344: 721-724 (1994). 
30 Scheller S, Wilczok T, Imielski S, Krol W, Gabrys J and Shani J, Free radical scavenging by ethanol extract of propolis. Int J Radiat Biol 57: 461-465 (1990).

31 Russo A, Longo R, Vanella A, Antioxidant activity of propolis: role of caffeic acid phenethyl ester and galangin. Fitoterapia 73 (Suppl 1): S21-29 (2002).

32 Chao Y, Liping L, Haijing Z, Xu Y, Yu L, Huanlu S, Common aroma-active components of propolis from 23 regions of China. J Sci Food Agr 90: 1268-1282 (2010).

33 González de Mejía E, Soo Song Y, Heck C.I, Ramírez-Mares MV, Yerba mate tea (Ilex paraguariensis): Phenolics, antioxidant capacity and in vitro inhibition of colon cancer cell proliferation. J Funct Foods 2: 23 -34 (2010).

34 Fini L, Selgrad M, Fogliano V, Graziani G, Romano M, Hotchkiss E, Daoud YA, De Vol EB, Boland RC, Ricciardiello L, Annurca Apple Polyphenols Have Potent Demethylating Activity and Can Reactivate Silenced Tumor Suppressor Genes in Colorectal Cancer Cells. J Nutr 137: 2622-2628 (2007).

35 Fleischauer AT, Poole C, Arab L, Garlic consumption and cancer prevention: Metaanalyses of colorectal and stomach cancers. Am J Clin Nutr 72: 1047-1052 (2000). 
Table 1. Concentration of analyzed phenolic compounds in ethanolic extracts of propolis

\begin{tabular}{|c|c|c|c|c|c|c|c|c|}
\hline \multirow{2}{*}{ Compound } & \multirow{2}{*}{$\begin{array}{l}\text { Retention } \\
\text { time } \\
(\mathrm{min})\end{array}$} & \multicolumn{7}{|c|}{ Concentration ( $\mu \mathrm{g} \mathrm{mg}^{-1}$ of EEP) } \\
\hline & & S1 & $\mathbf{S 2}$ & $\mathbf{S 3}$ & S4 & S5 & S6 & S7 \\
\hline $\begin{array}{l}p \text { - } \\
\text { hydroxybenzoic } \\
\text { acid }\end{array}$ & 4.64 & $0.256 \pm 0.003$ & $0.251 \pm 0.003$ & $0.180 \pm 0.002$ & $0.235 \pm 0.003$ & $0.281 \pm 0.003$ & $0.232 \pm 0.003$ & $0.215 \pm 0.002$ \\
\hline caffeic acid & 5.91 & $8.931 \pm 0.098$ & $7.919 \pm 0.087$ & $3.372 \pm 0.040$ & $7.271 \pm 0.079$ & $8.872 \pm 0.095$ & $6.968 \pm 0.077$ & $5.989 \pm 0.072$ \\
\hline $\begin{array}{l}p \text {-coumaric } \\
\text { acid }\end{array}$ & 7.75 & $3.553 \pm 0.043$ & $3.515 \pm 0.047$ & $4.488 \pm 0.049$ & $3.582 \pm 0.047$ & $4.649 \pm 0.047$ & $3.663 \pm 0.045$ & $3.726 \pm 0.049$ \\
\hline ferulic acid & 8.61 & $2.601 \pm 0.033$ & $2.209 \pm 0.029$ & $7.584 \pm 0.086$ & $3.482 \pm 0.053$ & $4.989 \pm 0.059$ & $3.382 \pm 0.047$ & $4.546 \pm 0.058$ \\
\hline isoferulic acid* & 8.99 & $0.336 \pm 0.041$ & $0.289 \pm 0.034$ & $2.448 \pm 0.036$ & $5.490 \pm 0.061$ & $6.624 \pm 0.063$ & $5.263 \pm 0.059$ & $4.460 \pm 0.039$ \\
\hline myricetin & 10.51 & $0.613 \pm 0.007$ & $0.647 \pm 0.009$ & $0.500 \pm 0.006$ & $0.614 \pm 0.008$ & $0.703 \pm 0.008$ & $0.635 \pm 0.007$ & $0.572 \pm 0.006$ \\
\hline luteolin & 13.81 & $0.853 \pm 0.010$ & $0.922 \pm 0.011$ & $0.667 \pm 0.007$ & $0.823 \pm 0.010$ & $0.898 \pm 0.011$ & $0.789 \pm 0.009$ & $0.750 \pm 0.008$ \\
\hline quercetin & 14.27 & $2.849 \pm 0.034$ & $2.893 \pm 0.035$ & $1.696 \pm 0.023$ & $2.746 \pm 0.029$ & $3.457 \pm 0.045$ & $2.664 \pm 0.031$ & $2.427 \pm 0.027$ \\
\hline naringenin & 17.87 & $0.928 \pm 0.011$ & $0.960 \pm 0.012$ & $1.328 \pm 0.018$ & $0.961 \pm 0.012$ & $1.230 \pm 0.015$ & $0.981 \pm 0.014$ & $1.668 \pm 0.019$ \\
\hline apigenin & 18.33 & $3.860 \pm 0.047$ & $3.841 \pm 0.045$ & $2.469 \pm 0.021$ & $3.929 \pm 0.049$ & $4.658 \pm 0.056$ & $3.653 \pm 0.035$ & $3.345 \pm 0.029$ \\
\hline kaempferol & 19.20 & $4.625 \pm 0.051$ & $3.834 \pm 0.041$ & $2.445 \pm 0.031$ & $3.588 \pm 0.037$ & $4.636 \pm 0.052$ & $3.520 \pm 0.028$ & $3.197 \pm 0.024$ \\
\hline hesperetin & 19.79 & $0.415 \pm 0.035$ & $0.389 \pm 0.032$ & $0.661 \pm 0.039$ & $0.347 \pm 0.028$ & $0.448 \pm 0.036$ & $0.372 \pm 0.039$ & $0.453 \pm 0.036$ \\
\hline isorhamnetin & 20.05 & $0.950 \pm 0.048$ & $0.840 \pm 0.041$ & $1.855 \pm 0.019$ & $0.804 \pm 0.039$ & $0.869 \pm 0.042$ & $0.779 \pm 0.038$ & $0.763 \pm 0.037$ \\
\hline chrysin & 33.03 & $34.124 \pm 0.375$ & $29.687 \pm 0.327$ & $16.665 \pm 0.183$ & $35.555 \pm 0.381$ & $40.811 \pm 0.449$ & $28.490 \pm 0.311$ & $26.729 \pm 0.294$ \\
\hline pinocembrin & 34.87 & $35.546 \pm 0.379$ & $35.322 \pm 0.368$ & $15.244 \pm 0.175$ & $32.672 \pm 0.325$ & $40.324 \pm 0.401$ & $31.934 \pm 0.311$ & $27.150 \pm 0.302$ \\
\hline galangin & 36.21 & $30.432 \pm 0.287$ & $29.771 \pm 0.276$ & $12.697 \pm 0.128$ & $27.389 \pm 0.295$ & $35.586 \pm 0.374$ & $27.122 \pm 0.288$ & $23.119 \pm 0.254$ \\
\hline $\begin{array}{l}\text { caffeic acid } \\
\text { phenylethyl } \\
\text { ester** }\end{array}$ & 38.71 & $6.552 \pm 0.072$ & $7.075 \pm 0.079$ & $6.053 \pm 0.067$ & $6.869 \pm 0.076$ & $8.209 \pm 0.090$ & $7.153 \pm 0.079$ & $6.637 \pm 0.073$ \\
\hline tectochrysin & 57.31 & $6.247 \pm 0.074$ & $5.571 \pm 0.068$ & $2.831 \pm 0.029$ & $4.336 \pm 0.049$ & $6.255 \pm 0.075$ & $5.239 \pm 0.067$ & $4.477 \pm 0.051$ \\
\hline
\end{tabular}

Results are mean values \pm SD from at least three experiments

* Semiquantitatively determined from the calibration curve of ferulic acid

**Semiquantitatively determined from the calibration curve of caffeic acid 
Table 2. Growth inhibitory effects- $\mathrm{IC}_{50}$ values $\left(\mu \mathrm{g} \mathrm{mL} \mathrm{m}^{-1}\right)$ of ethanolic extracts from different propolis samples on HCT-116 cell line after $24 \mathrm{~h}$ and $72 \mathrm{~h}$ of exposure. $\mathrm{IC}_{50}$ values were determined by linear regression analysis.

\begin{tabular}{lll}
\hline Sample & \multicolumn{2}{c}{$\mathbf{I C}_{\mathbf{5 0}}\left(\boldsymbol{\mu g} \mathbf{~ m L}^{-\mathbf{1}}\right)$} \\
S1 & \multicolumn{1}{c}{$24 \mathrm{~h}$} & \multicolumn{1}{c}{$\mathrm{h}$} \\
\cline { 2 - 3 } S2 & $184.08 \pm 14.83$ & $65.58 \pm 3.24$ \\
S3 & $466.72 \pm 0.53$ & $143.09 \pm 2.66$ \\
S4 & $464.21 \pm 19.2$ & $65.13 \pm 1.13$ \\
S5 & $191.13 \pm 5.62$ & $26.33 \pm 2.97$ \\
S6 & $451.04 \pm 7.16$ & $39.81 \pm 1.01$ \\
S7 & $388.55 \pm 8.17$ & $38.54 \pm 1.56$ \\
5-Fluorouracil & $0.018 \pm 0.004$ & $0.81 \pm 0.49$ \\
\hline
\end{tabular}

Results are mean values $\pm \mathrm{SE}$ from at least three experiments. 5-Fluorouracil is positive control for propolis cytotoxic evaluation.

Table 3. Effect of EEP samples, on HCT-116 cell line after 24 and $72 \mathrm{~h}$ of exposure, on superoxide anion radical $\left(\mathrm{O}_{2}{ }^{--}\right)$production expressed as nmol $\mathrm{mL}^{-1}$.

\begin{tabular}{|c|c|c|c|c|c|}
\hline \multirow[b]{2}{*}{ Sample } & \multicolumn{5}{|c|}{ Concetration of EEP } \\
\hline & $0 \mu \mathrm{g} \mathrm{mL} \mathbf{L}^{-1}$ & $10 \mu \mathrm{g} \mathrm{mL}^{-1}$ & $\begin{array}{c}\mathbf{5 0} \boldsymbol{\mu g} \mathbf{~ m L}^{-1} \\
\text { after } 24 \mathrm{~h}\end{array}$ & $100 \mu \mathrm{g} \mathrm{mL}^{-1}$ & $500 \mu \mathrm{g} \mathrm{mL}^{-1}$ \\
\hline S1 & $33.02 \pm 2.05$ & $29.32 \pm 0.60 *$ & $30.03 \pm 0.84 *$ & $29.53 \pm 0.57 *$ & $30.96 \pm 0.42 *$ \\
\hline S2 & $33.02 \pm 2.05$ & $29.40 \pm 0.28 * \#$ & $29.87 \pm 0.63 * \#$ & $30.48 \pm 0.44 * \#$ & $30.18 \pm 0.11 * \#$ \\
\hline $\mathbf{S 3}$ & $33.02 \pm 2.05$ & $31.69 \pm 1 \#$ & $30.04 \pm 0.11 *$ & $30.48 \pm 0.88^{*}$ & $32.36 \pm 0.68 \#$ \\
\hline S4 & $33.02 \pm 2.05$ & $32.17 \pm 0.50 \#$ & $30.04 \pm 0.69 *$ & $30.70 \pm 0.10^{* \#}$ & $32.94 \pm 1.75$ \\
\hline S5 & $33.02 \pm 2.05$ & $29.10 \pm 0.61 * \#$ & $31.60 \pm 0.43 \#$ & $30.70 \pm 0.33 \#$ & $31.90 \pm 0.47 \#$ \\
\hline S6 & $33.02 \pm 2.05$ & $28.99 \pm 1.12 * \#$ & $29.98 \pm 1.16^{* \#}$ & $33.12 \pm 0.50 \#$ & $31.26 \pm 0.42$ \\
\hline S7 & $33.02 \pm 2.05$ & $30.70 \pm 0.37 * \#$ & $29.23 \pm 0.52 * \#$ & $30.36 \pm 0.60 *$ & $32.74 \pm 0.24 \#$ \\
\hline Sample & $0 \mu g \mathrm{~mL}^{-1}$ & $10 \mu \mathrm{g} \mathrm{mL}^{-1}$ & $\begin{array}{r}50 \boldsymbol{\mu g} \mathbf{~ m L}^{-1} \\
\text { after } 72 \mathrm{~h}\end{array}$ & $100 \mu \mathrm{g} \mathrm{mL}^{-1}$ & $500 \mu \mathrm{g} \mathrm{mL}^{-1}$ \\
\hline S1 & $32.16 \pm 0.40$ & $29.48 \pm 1.24 *$ & $29.66 \pm 0.64 *$ & $28.22 \pm 0.53 *$ & $28.25 \pm 1.74 *$ \\
\hline S2 & $32.16 \pm 0.40$ & $27.57 \pm 1.10^{*}$ & $27.76 \pm 0.44 *$ & $28.70 \pm 0.85^{*}$ & $28.49 \pm 0.68 *$ \\
\hline S3 & $32.16 \pm 0.40$ & $28.66 \pm 0.48^{*}$ & $29.30 \pm 0.42 *$ & $29.09 \pm 0.41 *$ & $30.54 \pm 0.35^{*}$ \\
\hline S4 & $32.16 \pm 0.40$ & $28.76 \pm 0.47^{*}$ & $29.30 \pm 0.70^{*}$ & $28.86 \pm 0.33 *$ & $32.01 \pm 0.47$ \\
\hline S5 & $32.16 \pm 0.40$ & $32.68 \pm 1.86$ & $22.76 \pm 0.72 *$ & $28.86 \pm 0.69 *$ & $33.32 \pm 0.99 *$ \\
\hline S6 & $32.16 \pm 0.40$ & $18.81 \pm 0.90 *$ & $23.04 \pm 0.32 *$ & $29.80 \pm 0.50 *$ & $32.54 \pm 0.52$ \\
\hline S7 & $32.16 \pm 0.40$ & $23.50 \pm 0.71 *$ & $23.48 \pm 0.59 *$ & $28.59 \pm 0.37^{*}$ & $34.42 \pm 0.25 *$ \\
\hline
\end{tabular}

All values are mean values \pm SE from at least three experiments, ${ }^{*} p<0.05$ compared with control and $\# p<0.05$ comparision after $24 \mathrm{~h}$ and $72 \mathrm{~h}$ of treatment. 
Table 4. Effect of ethanolic extracts from different propolis samples, on HCT-116 cell line after 24 and $72 \mathrm{~h}$ of exposure, on the nitrite $\left(\mathrm{NO}_{2}{ }^{-}\right)$production expressed as $\mathrm{nmol} \mathrm{mL}{ }^{-1}$.

\begin{tabular}{|c|c|c|c|c|c|}
\hline \multirow[b]{2}{*}{ Sample } & \multicolumn{5}{|c|}{ Concetration of EEP } \\
\hline & $0 \mu \mathrm{g} \mathrm{mL}^{-1}$ & $10 \mu \mathrm{g} \mathrm{mL^{-1 }}$ & $\begin{array}{c}\mathbf{5 0} \boldsymbol{\mu} \mathbf{g} \mathbf{~ m L}^{-1} \\
\text { after } 24 \mathrm{~h}\end{array}$ & $100 \mu \mathrm{g} \mathrm{mL}^{-1}$ & $500 \mu \mathrm{g} \mathrm{mL}^{-1}$ \\
\hline S1 & $19.30 \pm 0.14$ & $16.07 \pm 0.15^{*} \#$ & $14.73 \pm 0.41 * \#$ & $14.63 \pm 0.70 * \#$ & $14.70 \pm 0.15^{* \#}$ \\
\hline S2 & $19.30 \pm 0.14$ & $16.45 \pm 0.05^{*} \#$ & $15.75 \pm 0.27 * \#$ & $15.78 \pm 0.79 * \#$ & $14.29 \pm 0.40 * \#$ \\
\hline S3 & $19.30 \pm 0.14$ & $16.11 \pm 0.30 * \#$ & $14.75 \pm 0.73 * \#$ & $14.61 \pm 0.60^{* \#}$ & $16.77 \pm 0.24 * \#$ \\
\hline S4 & $19.30 \pm 0.14$ & $17.90 \pm 1.03 \#$ & $16.33 \pm 0.82 * \#$ & $16.17 \pm 0.70^{* \#}$ & $17.06 \pm 0.30 * \#$ \\
\hline S5 & $19.30 \pm 0.14$ & $16.84 \pm 0.20 * \#$ & $16.69 \pm 0.16^{* \#}$ & $16.63 \pm 0.26^{* \#}$ & $16.08 \pm 0.13 * \#$ \\
\hline S6 & $19.30 \pm 0.14$ & $17.47 \pm 0.43 * \#$ & $16.22 \pm 0.31 * \#$ & $16.01 \pm 0.19 * \#$ & $15.72 \pm 0.30 * \#$ \\
\hline S7 & $19.30 \pm 0.14$ & $17.78 \pm 0.20 * \#$ & $17.04 \pm 0.04 * \#$ & $17.90 \pm 0.26^{* \#}$ & $18.13 \pm 0.18^{* \#}$ \\
\hline Sample & $0 \mu \mathrm{g} \mathrm{mL}^{-1}$ & $10 \mu \mathrm{g} \mathrm{mL}^{-1}$ & $\begin{array}{r}\mathbf{5 0} \boldsymbol{\mu g} \mathbf{~ m L}^{-\mathbf{1}} \\
\text { after } 72 \mathrm{~h}\end{array}$ & $100 \mu \mathrm{g} \mathrm{mL}^{-1}$ & $500 \mu \mathrm{g} \mathrm{mL}^{-1}$ \\
\hline S1 & $17.49 \pm 0.42$ & $12.85 \pm 0.22 *$ & $9.90 \pm 0.27 *$ & $9.62 \pm 0.45^{*}$ & $10.54 \pm 0.37 *$ \\
\hline $\mathbf{S 2}$ & $17.49 \pm 0.42$ & $14.33 \pm 0.55^{*}$ & $7.38 \pm 0.44 *$ & $0.70 \pm 0 *$ & $1.48 \pm 0.01 *$ \\
\hline S3 & $17.49 \pm 0.42$ & $7.02 \pm 0.75 *$ & $2.60 \pm 0.21^{*}$ & $2.67 \pm 0.40^{*}$ & $13.49 \pm 0.72 *$ \\
\hline S4 & $17.49 \pm 0.42$ & $5.76 \pm 0.07 *$ & $7.87 \pm 0.23 *$ & $2.04 \pm 0.18 *$ & $19.81 \pm 0.60$ \\
\hline S5 & $17.49 \pm 0.42$ & $1.48 \pm 0.11^{*}$ & $3.79 \pm 0.18^{*}$ & $1.69 \pm 0.10^{*}$ & $6.18 \pm 0.19^{*}$ \\
\hline S6 & $17.49 \pm 0.42$ & $13.77 \pm 0.65^{*}$ & $3.79 \pm 0.23 *$ & $1.69 \pm 0.10^{*}$ & $9.48 \pm 0.40^{*}$ \\
\hline S7 & $17.49 \pm 0.42$ & $23.81 \pm 0.38 *$ & $9.27 \pm 0.27 *$ & $8.08 \pm 0.31 *$ & $29.15 \pm 0.43^{*}$ \\
\hline
\end{tabular}

All values are mean values \pm SE from at least three experiments, ${ }^{*} p<0.05$ compared with control and $\# p<0.05$ comparision after $24 \mathrm{~h}$ and $72 \mathrm{~h}$ of treatment.

Table 5. Free radical-scavenging activity of 2,2-diphenyl-1-picrylhydrazyl radical by ethanolic propolis extracts. $\mathrm{IC}_{50}$ values were determined by linear regression analysis.

\begin{tabular}{lll}
\hline Sample & \multicolumn{2}{c}{$\mathbf{I C}_{\mathbf{5 0}}\left(\boldsymbol{\mu g} \mathbf{~ m L}^{\mathbf{1}}\right)$} \\
& $30 \mathrm{~min}$ & $60 \mathrm{~min}$ \\
\cline { 2 - 3 } S1 & $70.42 \pm 20.32$ & $57.75 \pm 17.34$ \\
S2 & $103.88 \pm 27.66$ & $95.76 \pm 25.97$ \\
S3 & $87.13 \pm 27.42$ & $81.81 \pm 26$ \\
S4 & $55.45 \pm 20.61$ & $51.28 \pm 18.57$ \\
S5 & $118.46 \pm 36.44$ & $74.69 \pm 30.56$ \\
S6 & $75.75 \pm 23.21$ & $69.15 \pm 20.59$ \\
S7 & $56.68 \pm 19.62$ & $53.97 \pm 18.46$ \\
BHT & $25.4 \pm 22.70$ & $12.78 \pm 7.60$ \\
Asc & $42.4 \pm 22.70$ & $27.22 \pm 14.30$ \\
\hline
\end{tabular}

Results are mean values \pm SE from at least three experiments 
Figure 1. HPLC-DAD chromatogram $(\lambda=260 \mathrm{~nm})$ for EEP of sample S2

HPLC DAD chromatogram at $260 \mathrm{~nm}$ of EEP of sample S2. Peaks: 1, $p$-hydroxybenzoic acid; 2, caffeic acid; 3, $p$-coumaric acid; 4, ferulic acid; 5, isoferulic acid; 6, myricetin; 7, luteolin; 8, quercetin; 9, naringenin; 10, apigenin; 11, kaempferol; 12 , hesperetin; 13, isorhamnetin; 14, chrysin; 15, pinocembrin; 16, galangin; 17, caffeic acid phenylethyl ester; 18 , tectochrysin.

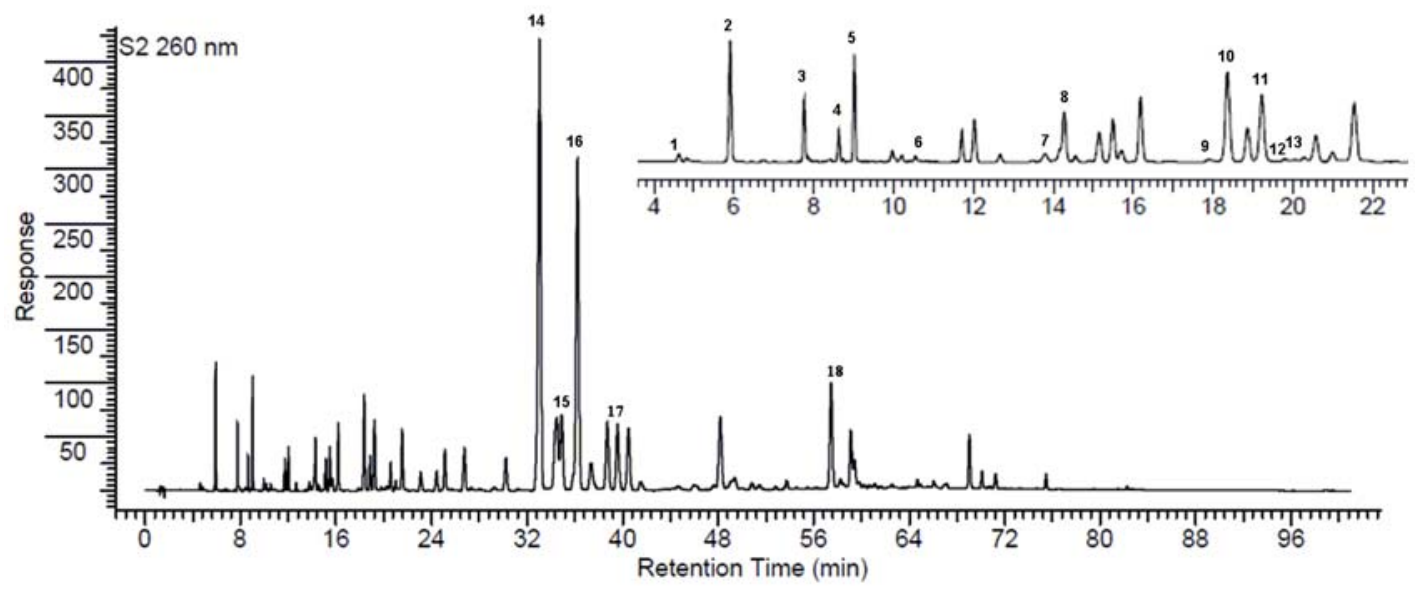

Figure 2. The dose-response curves of the effects of ethanolic propolis extracts (S1-S7) on cell growth of HCT-116 cells. The cells were treated with various concentrations of drugs for $24 \mathrm{~h}$ and $72 \mathrm{~h}$. The cytotoxic effects were measured by MTT assay.

Results were expressed as mean values $\pm \mathrm{SE}$ for three independent determinations. 


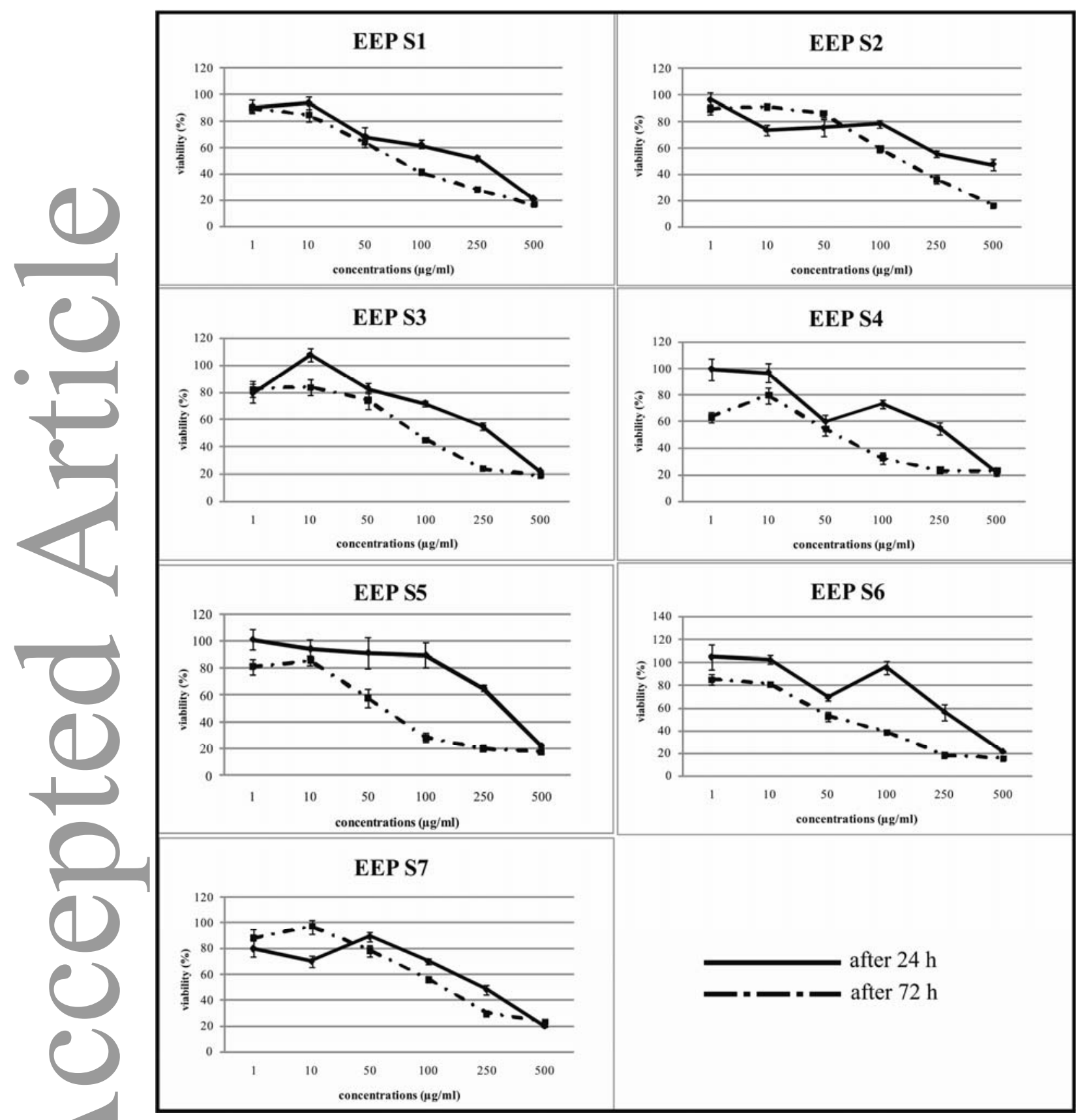

